\title{
The Contribution of Forests from Counties Located in Romania's West Plain to The Area's Long Lasting Development
}

\author{
Ilie-Cosmin Cântar ${ }^{1}$ \& Lucian-Constantin Dinca ${ }^{2}$ \\ 1 "Marin Drăcea” National Institute for Research and Development for Forestry, Timișoara, Romania \\ 2 "Marin Drăcea" National Institute for Research and Development for Forestry, Braşov, Romania \\ Correspondence: Lucian Dincă, National Institute for Research and Development for Forestry "Marin Drăcea", \\ Cloşca Street, 13, Braşov - 500040, Romania. Tel: 1-613-947-3592. E-mail: dinka.lucian@gmail.com
}

Received: December 31, 2021 Accepted: January 21, $2021 \quad$ Online Published: June 4, 2021

\begin{abstract}
The present paper reunites in an objective synthesis data from forest management plans realized in the West Plain during 1995-2008. The study focused on stands situated around cities and in their construction perimeter in order to emphasise their contribution to the area's long lasting development. The paper's importance derives from the fact that urban areas are in a continuous development that will incorporate heavily nearby forests. As such, through their functions, forests contribute to the long lasting development of the entire metropolitan area to which they belong. All forests from the West Plain were divided in stand elements (species of a certain age that belong to a forest's composition). The study has taken into account all stand elements from the area that belongs to the forest category from around cities. The large number of these stand elements (2107) offers a solid base for the different realized analyses. The paper's results show that from the entire surface of forests with recreation functions located in the West Plain, 4.670 ha are occupied by Forests from around counties, cities and villages as well as forests located in their construction perimeter. The most widespread species from this type of stand is pedunculate oak (Quercus robur L.), which occupies 2072 ha. Forests from around cities from the West Plain are situated at altitudes between 80 and $400 \mathrm{~m}$. The soils are predominantly common alvisol, while Arum-Pulmonaria is the most widespread flora. In the context of the long lasting development of urban areas with implications on nearby forests, the results and discussions of this article represent a first step towards knowing these forests and towards properly managing them in order to successfully fulfil their protection and recreational purposes.
\end{abstract}

Keywords: West Plain, stands, long lasting development, species, cities

\section{Introduction}

West Plain is the Romanian part of Tisa's Plain, belonging to Danube's plain, named by Hungarian and international geographers as "The Grand Hungarian Plain" or "The Pannonia Basin" (fig. 1). The plain covers a length of $375 \mathrm{~km}$ and an average width of $45 \mathrm{~km}$. The West Plain is bordered on North by Tur River, on East by the West Hills and Occidental Carpathians, by West by Hungary and Serbia and on South by Serbia. The relief is composed of three levels: plains higher than $100 \mathrm{~m}$ (the oldest, dating back to the Pleistocene and located towards the hills), horizontal, smooth plain (presents sand accumulations) and low plain (where rivers tend to create swamps). The climate is continental, with average annual temperatures between $10-12^{\circ} \mathrm{C}$. Differences can be observed in the north part $\left(9-10^{\circ} \mathrm{C}\right)$ as well as in the south one $\left(10-11^{\circ} \mathrm{C}\right)$. Annual average precipitations range between $550-600 \mathrm{~mm}$. Natural vegetation remains only on extremely narrow surfaces. Soils belong to the molisoil class (cernoziom) and intrazonal soils (hydromorphic, halomorphic, psamosoils in Carei Plain) (https://ro.wikipedia.org/).

In regard to human settlements, this area contains 18 urban establishments with 4 being county capitals: Timișoara, Arad, Oradea, Satu Mare. Rural settlements are rare, large (over 3000 inhabitants) and have a geometrisation degree that accentuates from north to south (www.geocities.com).

Satu Mare is the capital of the county with the same name and which is formed of Satu Mare (capital) and Sătmărel. In the past, Satu Mare was the capital of Sătmar Shire and of Satu Mare County (between the wards). Its population amounted to 102.411 inhabitants in 2011 (Romania's population census, 2011).

Oradea is the capital of Bihor County, being situated in West Romania, on Crișul Repede river, and near Hungary's border. Furthermore, Oradea is the most important city from the historical region of Crișana. In the 2002 census, 
the city had 206.614 inhabitants. The metropolitan area, which includes 11 nearby villages, had in 2002 a population of 249.746 inhabitants (www.zmo.ro).

Arad is the capital city of the county with the same name, situated at the limit between Banat and Crişana historical regions. The city is located on both shores of Mureș River in Crișana and Banat. In the 2011 census, Arad had a population of 159.074 inhabitants. Arad municipality is the main entrance gate in Romania, being the most important car and train knot from West Romania. As such, Arad is situated at $17 \mathrm{~km}$ from Curtici - the largest train customs point from our country's west part. Arad is located in Romania's West extremity, south of Crișana and north of Banat (Rusu, 2007).

Timișoara is the capital city of Timiș County, situated near the borders with Hungary and Serbia and on Bega River. In 2011, Timișoara had 319.279 inhabitants, being the third city in Romania. Timișoara's municipality area has a population of 468.162 inhabitants (https://ro.wikipedia.org/).

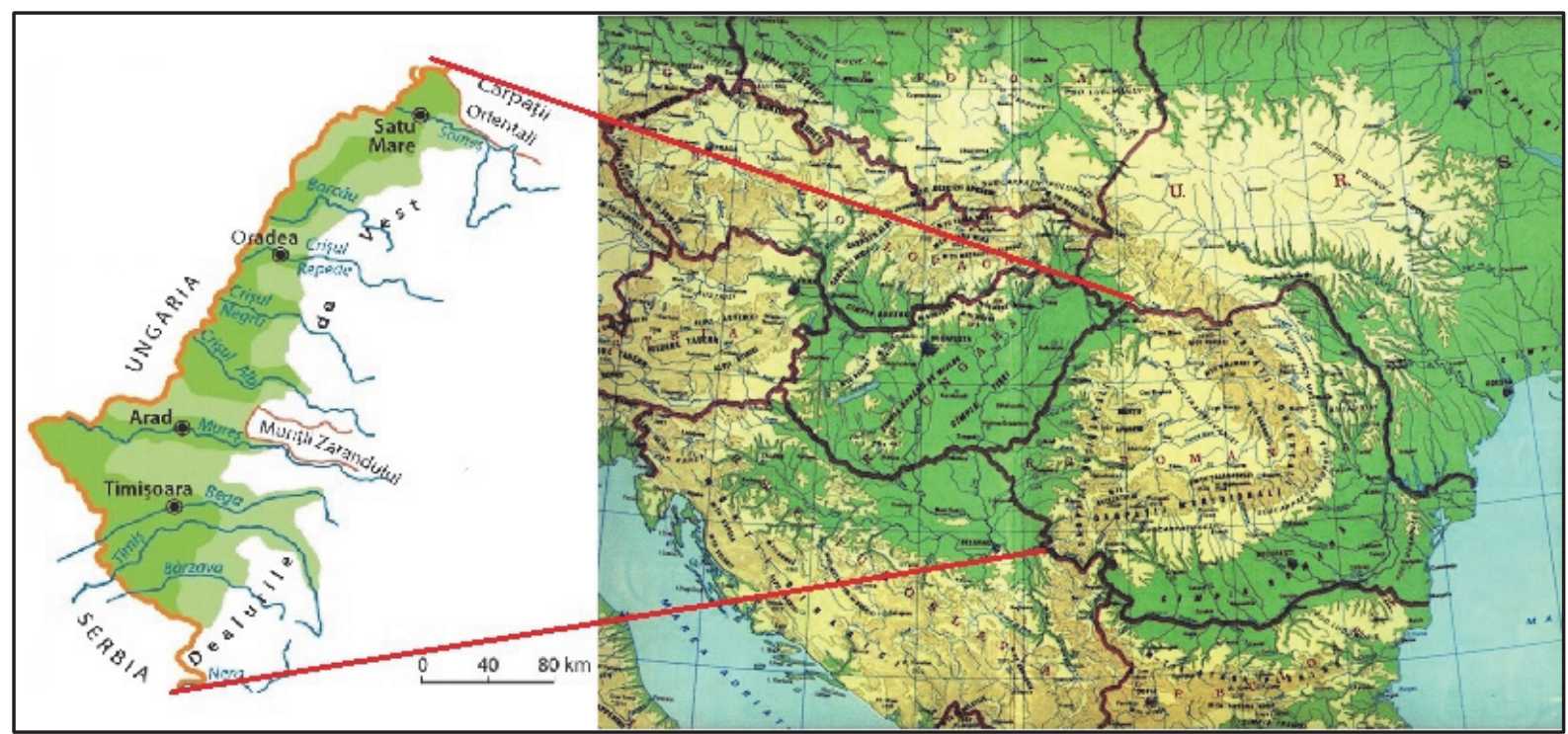

Figure 1. Location of West Plain in Romania and in Europe (Source: www.geotutorials.ro)

The hypothesis of this paper is that the forests in western Romania contribute to the sustainable development of the area from an economic point of view and not only, by increasing activities in the field of wood and non-timber products, increasing the recreational role of forests and tourism in the area and implicitly the increase of the quality of life in the studied area.

It is well known that by assuming the role of active surface, the forest modifies substantially the regime of climate factors from the surface that it occupies, creating its own microclimate. Also known as forest phitoclimate, this climate is different from the region's climate (macroclimate) as well as from the topoclimate (Constandache et al., 2018; Vlad et al., 2019). This function becomes active and assumes the functions exercised by the soils surface from the moment of closing the massive state. Only now, two strongly shaping factors intervene: the leaf (which generates shadow and absorbs part of the solar radiation) and albedo (which rejects a part of this radiation) (Chisăliţă, 2001).

The positive role that forest vegetation has in refreshing the air and in regulating the debit of running waters is recognised wordlwide (Constandache et al., 2019; Dinca et al., 2019); furthermore, it also represents a shield against wind and noises. Forest vegetation from around industrial units with strong harmful emissions contributes to air purification by neutralising pollutants, retaining powders, preventing the propagation of harmful substances and diminishing noises (Kachova et al., 2015; Popov et al., 2017). The forest increases the irregularity of earthly surfaces, forming obstacles that increase the turbulence of wind currents and the dilution of emissions. Differentiated heating, namely the cooling of forest surfaces during the night, causes vertical movements that lead to replacing damaged air with fresh air. The oxygen eliminated by the forest is transported by air currents at very large distances, refreshing the polluted atmosphere from cities and industrial areas.

Besides these roles of protecting against harmful anthropic factors and creating a specific microclimate, forests have an important recreational and scenery purpose that can be especially valued in forests from around urban centres. 
As such, the importance of the present paper is given by the fact that the continuous development from around cities leads to the incorporation of many territories that previously belong to unincorporated areas. As such, forests situated today near large urban centres will represent green oasis for "tomorrow's" cities and will contribute through their services to the long lasting development of the entire metropolitan area to which they belong.

The objective of this paper is to prove the contribution of forests from counties located in Romania's West Plain to the area's long lasting development by highlighting the characteristics of the main periurban forests in the studied area.

\section{Method}

Even from the XVI century, forests have been classified in forests destined to wood production (production forests) and forests destined to fulfil certain protection functions (protection forests) (Endres, 1922, în Rucăreanu, 1967). Professor Viktor Dieterich (1953) has introduced the theory of forest functions in silviculture, which included production functions, protection functions and social functions (Blum, 2004). Nowadays in Europe, it is considered that forests fulfil the following functions: a. Ecologic: 1. adjusting climate, air quality, aquatic systems and soil potential; 2. protecting against natural risks and noises; 3 . conserving biodiversity; b. Economic: production (wood and other wood and non-wood products), activities and services; c. Social: scenery, recreation, educational, cultural and social purposes (Hasanagas, N. D., \& Shoesmith, R. (2002); Blum, 2004).

According to technical norms for managing forests and to technical norms for choosing and applying treatments, forests are classified in Romania in two functional groups, based on their functions: Group 1: Forests with special protection functions and Group 2: Forests with production and protection functions. In their part, functional group 1 is divided in five subgroups, from which the fourth is named Forests with recreation functions. This subgroup was divided in 11 functional categories which include category 1,4B $=$ Forests from around counties, cities and villages, as well as forests situated in their building perimeter. The purpose of this study is represented by forests from the West Plain situated in this functional category.

All forests from the West Plain were divided in stand elements (species of a certain age that are part of a forest). The present paper has used all stand elements from this area that belong to the forest category from around cities (*** Forest management plans). The very large number of these stand elements (2107) offers a solid base for the different analyses realized. These analyses referred to: forest surface, their distribution areas, altitude, flora, soils, specific forest types, comprising tree species, age, lopping, stand composition and stand structure.

\section{Results}

The surface of forests from Subgroup 4. Forests with recreation functions occupy a total surface of 15.899 ha in the West Plain. Amongst them, the functional category 1,4B= Forests from around counties, cities and villages as well as the forests from their building perimeter is distributed on $4.670 \mathrm{ha}$. From the total number of forests situated in subgroup 4, the county forests are situated on the second place (29\%) after forests that present an exceptional game interest (1-4J, $55 \%$ ), (Figure 2).

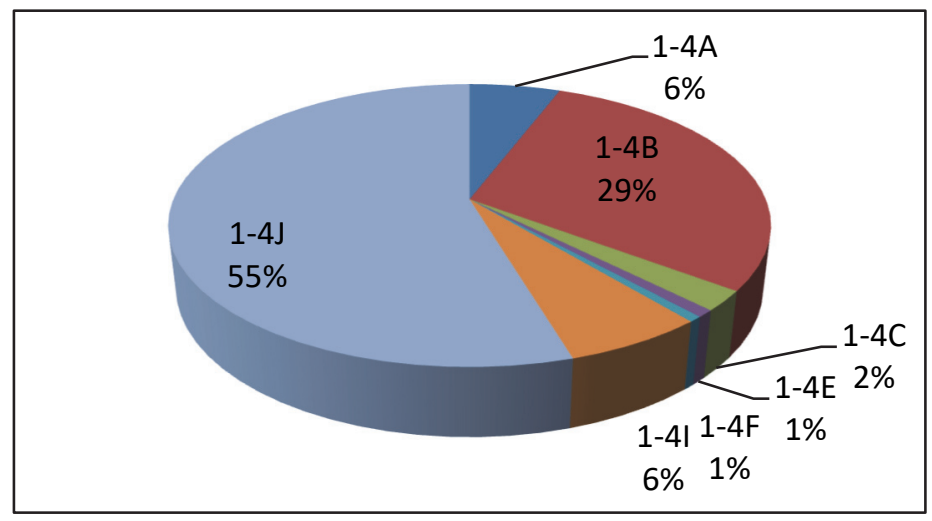

Figure 2. Surface occupied by forest functional categories from the subgroup Forests with recreation functions in the West Plain

The altitude characteristic for stands from this area ranges between $80 \mathrm{~m}$ (Timisului Meadow) and $400 \mathrm{~m}$ (Savarsin). The average altitude of these stands is of $110 \mathrm{~m}$ and was obtained by calculating the average altitudes of all 2107 analyzed stands. 
The flora characteristic for these stands is Arum-Pulmonaria $=1829$ ha and Erachypodium-Geum-Pulmonaria $=$ 1053 ha, while the most widespread flora elements are Carex-Poa pratensis $=749$ ha, Festuca pseudovina $=251$ ha, followed by Asperula-Asarum $=169$ ha, Carex riparia-Iris pseudacorus $=142$ ha, Genista tinctoria-Poa nemoralis $=134$ ha and Carex brizoides-Agrostis alba $=119$ ha,

The soils most common for these stands are: Common Aluviosol $=883$ ha, Red vertic-stagnic preluvosol $=870$ ha, Luvosol rodic stagnic $=538$ ha, Stagnic luvosol $=480$ ha, Clay molic preluvosol $=376$ ha, Red molic Preluvosol $=264$ ha, Common luvosol $=182$ ha, Common red Preluvosol $=168$ ha, Common Eutricambosol $=$ 146 ha.

The most representative forest types are: Meadow tug from our south country's silvosteppe and steppe $=689$ ha, Meadow oak tug of average productivity $=522$ ha, Plain normal cer $=510$ ha, Normal plain oak tug of average productivity $=482 \mathrm{ha}$, Shore and hill plateau oak stand of superior productivity $=456$ ha, Plain meadow oak stand $=$ 254 ha, Normal plain oak tug $=104$ ha, Plain divagation oak stand= 76 ha.

The species with the largest spread in the West Plain that belong to these forests are: pedunculate oak (Quercus robur L. $)=2072$ ha, turkey oak (Quercus cerrois L. $)=753$ ha, ash $($ Fraxinus excelsior L. $)=623$ ha, black locust $($ Robinia pseudoacacia L.) $=337$ ha, hornbeam (Carpinus betulus L.) $=217$ ha, and sessile oak (Quercus petraea L.) $=199$ ha (Figure 3).

Other species that can be found in these forests are: field maple (Acer campestre L.), Hungarian oak (Quercus frainetto L.), black walnut (Juglans nigra L.), red oak (Quercus rubra L.), beech (), European beech (Fagus sylvatica L.), Norway maple (Acer platanoides L.), field elm (Ulmus minor Mill.) and lime (Tilia cordata Mill.).

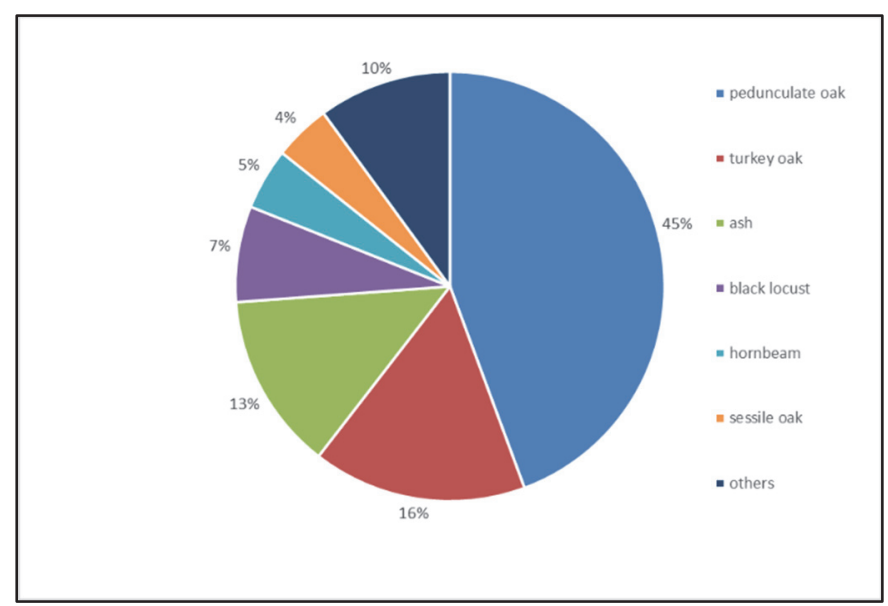

Figure 3. The surface occupied by species in forests from around cities in the West Plain

The age of stands that create forests around cities in the West Plain is very varied. The largest surfaces present stand elements situated in the 61-80 years category (Figure 4). Significant surfaces are also occupied by young stands (under 60 years old), as well as by older stands (81-100 years and 101-120 years). Stands older than 120 years occupy reduced surfaces, while the very old ones occupy very few surfaces. 


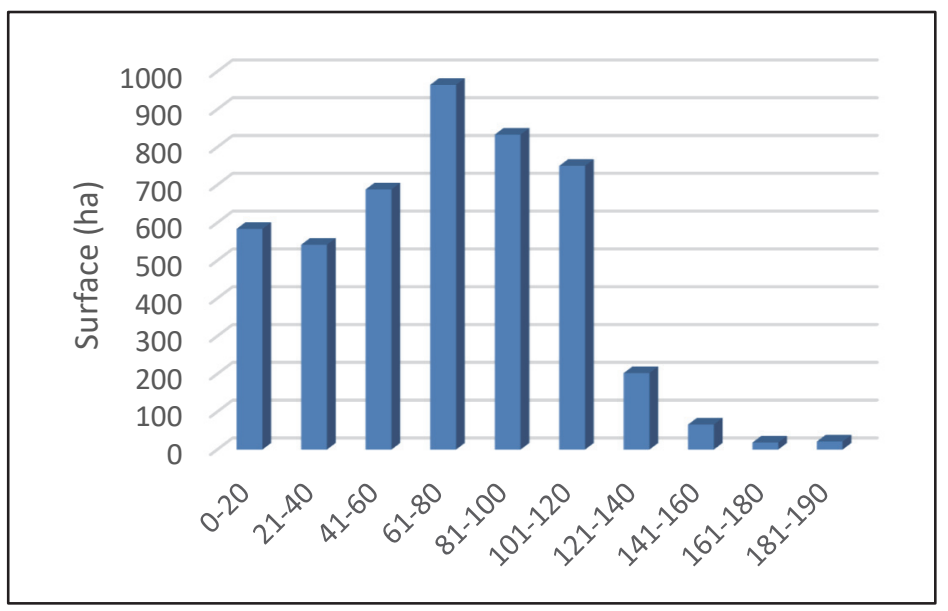

Figure 4. Age of the stands from around cities in the West Plain

The pruning of trees from these stands ranges between 0 and 0.7 , with a majority situated between 0.5 and 0.6 .

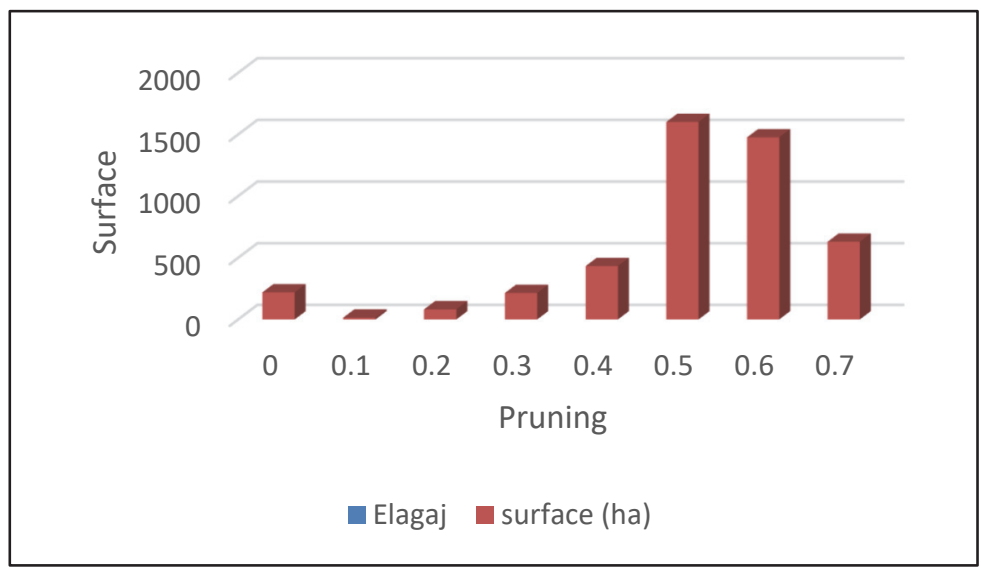

Figure 5. Tree pruning in forests from around cities in the West Plain

\section{Discussion}

Forests located around cities are widespread in forest districts situated near big cities from the West Plain, such as Lunca Timisului (for Timisoara) $=2672 \mathrm{ha}$, OS Ceala $($ for Arad $)=986 \mathrm{ha}$, OS Oradea $=299$ ha, OS Satu Mare $=$ $114 \mathrm{ha}$, as well as near smaller cities such as OS Tinca $=269$ ha, OS Radna $=201$ ha, OS Livada $=86$ ha, and OS Savarsin $=43$ ha. These significant surfaces offer the possibility of integrating these forests in the city's urbanistic and development plans. A long lasting development can be possible in the future by incorporating these forests that can become forests parks for local communities, fulfilling recreational purposes.

The soil types identified in these forests are rich in humus and nutritive elements (Spârchez et al., 2017; Cântar and Dincă, 2018; Dinca et al., 2019; Oneț et al., 2019). As such, they are favourable to forest vegetation (Chisăliță et al., 2015), and have only one impediment, namely water supply during drought periods (Dincă et al., 2018).

Analysing tree species from forests around cities in the West Plain, reveal a very rich range of species that emphasize these forests' recreational and scenery purposes and stand them apart from other national areas (Blaga et al., 2019; Constandache et al., 2019; Murariu et al., 2018).

\section{Conclusions}

The safety of using these forests in recreational purposes is increased by the small number and few surfaces occupied by old trees which can endanger inhabitants during extreme meteorological phenomenon.

Unlike the flora or soil, where the first two types occupy significant surfaces, the forest types are different. Furthermore, a large number of forest types are recorded (42 types), which indicate a large biodiversity of the 
analysed forests, as well as the tree's capacity to form varied association in these climate and relief conditions. As such, biodiversity is beneficial for communities and for their long lasting development.

Both the rich range of species, as well as the age of these stands have a positive effect on the long lasting development of communities for forests located around cities or in their building perimeter. On one hand, they ensure optimum conditions for using these forests in recreational purposes while, on the other hand, they can ensure when needed a handy wood mass on large areas and with different wood essences that can have multiple usages (from fire wood to industrial means).

Tree pruning shows that most of the stands are well pruned (with values between 0.5-0.6), area easy to cover in recreational purposes and have an enjoyable aspect from a scenery point of view.

\section{References}

Management plans of forest departments: Carei (2008), Ceala (2001), Chișinău Criș (2001), Livada (2001), Lugoj (1999), Lunca Timișului (2007), Oradea (2007), Radna (1995), Satu Mare (2004), Săcuieni (2008), Săvârșin (2005), Tinca (2004), Timișoara (2007).

Final results of population census 2011: Table 8. Stable population by ethnicity - counties, municipalities, cities, communes". Romanian National Institute of Statistics, July 2013.

Blaga, T., Dinca, L., \& Pleșca, I. M. (2019). How can smart alder forests (Alnus glutinosa (L.) Gaertn.) from the Southern Carpathians be indentified and managed. Scientific papers series, Management, Economic Engineering in Agriculture and Rural Development, 19(4), 29-35.

Blum, A. W. (2004). Forest functions. In Encyclopedia of forest sciences (pp. 1121-1126). Elsevier.

Cântar, I. C., \& Dincă, L. (2018). The forest soils from Arad County. Annals of the University of Craiova, Series Biology, Horticulture, Food produce processing technology, Environmental engineering, 23(59), 345-351.

Chisăliță, I., Dincă, L., Spârchez, G., Crăciunescu, A., \& Vișoiu, D. (2015). The influence of some stagnoluvisols characteristics on the productivity of Quercus cerris and Quercus frainetto stand from O.S. Făget, D.S. Timiș. Research Journal of Agricultural Science, Timisoara, 47(3), 23-28.

Constandache, C., \& Dincă, L. (2019). The management of pine stands situated outside their habitat. Scientific papers series, Management, Economic Engineering in Agriculture and Rural Development, 19(4), 59-65.

Constandache, C., Dinca, L., Popovici, L., Braga, C., \& Blaga, T. (2018). The effect of climatic changes over some Romanian forest ecosystems". 18 ${ }^{\text {th }}$ International Multidisciplinary Scientific Geoconference SGEM 2018. Conference proceedings, Volume 18, Water resources, Forest, Marine and ocean ecosystems, Issue 3.2. Soils, Forest Ecosystems, Marine and ocean ecosystems, pag. 941-948. https://doi.org/10.5593/sgem2018/3.2/S14.121

Constandache, C., Dincă, L., Tudor, C., \& Oneț, C. (2019). The ecological reconstruction of forest ecosystems affected by landslides. Natural Resources and Sustainable Development, 9, 144-159. https://doi.org/10.31924/nrsd.v9i2.032

Dincă, L., \& Achim, F. (2019). The management of forests situated on fields susceptible to landslides and erosion from the Southern Carpathians. Scientific papers series Management, Economic Engineering in Agriculture and Rural Development, 19(3), 183-188. https://doi.org/10.37358/RC.19.7.7342

Dinca, L., Badea, O., Guiman, G., Braga, C., Crisan, V., Greavu, V., Murariu, G., \& Georgescu, L. (2018). Monitoring of soil moisture in Long-Term Ecological Research (LTER) sites of Romanian Carpathians. Annals of Forest Research, 61(2), 171-188. https://doi.org/10.15287/afr.2018.1188

Dinca, L., Chisalita, I., \& Cantar, I. C. (2019). Chemical properties of forest soils from Romania's West Plain. Revista de Chimie, 70(7), 2371-2374.

Hasanagas, N. D., \& Shoesmith, R. (2002). The role of the European Parliament in forest environment issues. European Environment, 12(4), 213-223. https://doi.org/10.1002/eet.296

Kachova, V., \& Dincă, L. (2015). Establishment of agro-forestry systems along river basins-Functions and features. Revista de Silvicultură și Cinegetică, 20(36), 64-68.

Murariu, G., Murariu, A. G., Iticescu, C., Stanciu, S., \& Dinca, L. (2018). Investigation of growth rate assessment for locust (Robinia pseudoacacia) in the Eastern Romania. International Scientific Conference on EARTH and GEOSCIENCES-Vienna GREEN Scientific Sessions, 18(1.5), 711-718. https://doi.org/10.5593/sgem2018V/1.5/S03.086 
Onet, A., Dincă, L. C., Grenni, P., Laslo, V., Teusdea, A. C., Vasile, D. L., Enescu, R. E., \& Crisan, V. E. (2019). Biological indicators for evaluating soil quality improvement in a soil degraded by erosion processes. Journal of Soils and Sediments, 19(5), 2393-2404. https://doi.org/10.1007/s11368-018-02236-9

Popov, E., Hinkov, G., Kachova, V., Constandache, C., \& Dincă, L. (2017). A brief review of forest shelter belt establishments in Bulgaria and Romania. Revista de Silvicultură și Cinegetică, 41, 16-23.

Rucăreanu, N. (1967). Amenajarea pădurilor. Editura Agro-Silvică.

Rusu, R. (2007). Organizarea spațiului geografic în Banat, Editura Mirton, Timişoara.

Spârchez, G., Dincă, L., Marin, G., Dincă, M., \& Enescu, R. E. (2017). Variation of eutric cambisols' chemical properties based on altitudinal and geomorphological zoning. Environmental Engineering and Management Journal, 16(12), 2911-2918.

Vlad, R., Constandache, C., Dincă, L., Tudose, N.C., Sidor, C. G., Popovici, L., \& Ispravnic, A. (2019). Influence of climatic, site and stand characteristics on some structural parameters of scots pine (Pinus sylvestris) forests situated on degraded lands from east Romania. Range Management and Agroforestry, 40(1), 40-48.

\section{Web References}

https://www.geocities.com

https://www.geotutorials.ro

https://www.zmo.ro

\section{Copyrights}

Copyright for this article is retained by the author(s), with first publication rights granted to the journal.

This is an open-access article distributed under the terms and conditions of the Creative Commons Attribution license (http://creativecommons.org/licenses/by/4.0/). 